ACTA UNIVER SITATIS NICOLAI COPERNICI DOI: http://dx.doi.org/10.12775/AUNC_ECON.2013.017 EKONOMIA XLIV nr 2 (2013) 261-275

Pierwsza wersja złożona 8 lipca 2012

ISSN

Końcowa wersja zaakceptowana 18 sierpnia 2013

2080-0339

Artur A. Trzebinski ${ }^{*}$

\title{
ZMIANY POLSKIEGO RYNKU FUNDUSZY INWESTYCYJNYCH W LATACH 1992-2011
}

\begin{abstract}
Z a r y s t r e ś c i. Fundusze inwestycyjne już od kilku lat stanowią ważne aktywa w portfelach inwestorów indywidualnych i instytucjonalnych. Ze względu na coraz mniej restrykcyjne przepisy prawne stają się konkurencyjne w stosunku do innych klas aktywów. Celem artykułu jest przedstawienie transformacji rynku funduszy powierniczych $\mathrm{w}$ fundusze inwestycyjne oraz dalsze zmiany w strukturze tego rynku, ze szczególnym uwzględnieniem roli determinant prawno-podatkowych.
\end{abstract}

S ł o w a k $1 \mathrm{u} \mathrm{c} \mathrm{z} \mathrm{ow} \mathrm{e:} \mathrm{fundusze} \mathrm{inwestycyjne,} \mathrm{fundusze} \mathrm{powiernicze,} \mathrm{TFI.}$

K 1 a s y fik a c j a JEL: G23, K23.

\section{WSTĘP}

Fundusze inwestycyjne ${ }^{1}$ obecne są na polskim rynku finansowym od ponad 20 lat. W latach 1992-1994 funkcjonowal tylko jeden fundusz, nie będąc żadną konkurencją dla lokat bankowych i obligacji Skarbu Państwa. Dopiero zmiana przepisów prawa w 1997 r. i przekształcenie funduszy powierniczych $\mathrm{w}$ inwestycyjne pozwoliło towarzystwom funduszy inwestycyjnych (TFI) na oferowanie inwestorom funduszy z różnymi strategiami inwestycyjnymi. Pojawiły się także pierwsze fundusze kierowane do inwestorów

\footnotetext{
* Adres do korespondencji: Artur Trzebiński, Uniwersytet Ekonomiczny w Poznaniu, KTPiPP, al. Niepodległości 10, 61-875 Poznań

${ }^{1}$ Przez fundusz inwestycyjny rozumie się osobę prawną, której wyłącznym przedmiotem działalności jest lokowanie środków powierzonych w dowolny sposób przez inwestorów (z wyłączeniem ubezpieczeniowych funduszy kapitałowych i pracowniczych funduszy emerytalnych).
}

(C) 2013 Uniwersytet Mikołaja Kopernika. All rights reserved. http://www.aunc.ekonomia.umk.pl 
instytucjonalnych. Osiaganie wyższych stóp zwrotu przez fundusze w porównaniu do lokat bankowych czy obligacji zwróciły uwagę inwestorów na te instrumenty finansowe.

Celem artykułu jest przedstawienie zmian w strukturze przedmiotowej i podmiotowej, jakie zaszły na rynku instytucji wspólnego inwestowania w Polsce w latach 1992-2011, ze szczególnym uwzględnieniem wpływu determinant prawno-podatkowych na ten rynek. Pokazano także współoddziaływanie determinant makro- i mikroekonomicznych.

Artykuł składa się z 4 części, z których każda odpowiada innemu okresowi. Poszczególne podokresy odpowiadają okresom obowiązywania ustaw. Czesść pierwsza (lata 1992-1997) dotyczy funkcjonowania funduszy powierniczych. Kolejna (1998-2001) przedstawia zmianę funduszy powierniczych w inwestycyjne. Trzecia (2001-2004) skupiona jest na dostosowywaniu oferty TFI do zmieniających się warunków zewnętrznych. Ostatnia poświęcona jest okresowi rok po wejściu Polski do Unii Europejskiej i kończy się na grudniu 2011 r. Opracowanie zamyka podsumowanie z wnioskami.

\section{ETAP 1 - FUNDUSZE POWIERNICZE (STYCZEŃ 1992-GRUDZIEŃ 1997)}

Fundusze inwestycyjne zaistniały w Polsce jako fundusze powiernicze na mocy prawa o publicznym obrocie papierami wartościowymi i funduszach powierniczych (ustawa z 22 marca $1991 \mathrm{r}$.). Zgodnie z tą ustawą fundusz powierniczy, który był zarządzany przez towarzystwo funduszy powierniczych, służył do zbiorowego lokowania środków w papiery wartościowe. Jedyną możliwością było lokowanie co najmniej 90\% aktywów w papiery wartościowe dopuszczone do publicznego obrotu, w tym nie więcej niż 5\% wartości aktywów netto funduszu w papiery wartościowe jednego emitenta. Dodatkowo fundusz nie mógł zmienić celu, dla którego został stworzony.

Tabela 1. Liczba i aktywa funduszy powierniczych w okresie 1992-1997

\begin{tabular}{ccccccc}
\hline Rok & 1992 & 1993 & 1994 & 1995 & 1996 & 1997 \\
\hline Liczba towarzystw funduszy powierniczych & 1 & 1 & 1 & 2 & 3 & 7 \\
Liczba funduszy & 1 & 1 & 1 & 4 & 5 & 20 \\
Aktywa funduszy (w mln zł), w tym (w \%): & 2 & 828 & 1423 & 693 & 1364 & 1901 \\
akcyjnych & 0 & 0 & 0 & 0,4 & 23 & 35 \\
obligacji & 0 & 0 & 0 & 1,1 & 3 & 3,3 \\
zrównoważonych & 100 & 100 & 100 & 98,5 & 74 & 61 \\
rynku pieniężnego i gotówkowe & 0 & 0 & 0 & 0 & 0 & 0,7 \\
\hline
\end{tabular}

Źródło: obliczenia i opracowanie własne na podstawie IZFiA i KPWG. 
Jak wynika z danych przedstawionych w tabeli 1, w latach 1992-1994 funkcjonowało tylko jedno towarzystwo i jeden fundusz. Tworzenie nowych funduszy było utrudnione przez ustawowe ograniczenia związane z dystrybucją tytułów uczestnictwa (sprzedaż jednostek uczestnictwa funduszy mogła mieć miejsce tylko w punktach obsługi klienta towarzystwa ${ }^{2}$ ). Negatywnie na rynek funduszy powierniczych wpływała także dwucyfrowa inflacja i wysokie bezrobocie, co zmniejszało skłonność gospodarstw domowych do oszczędzania (Dawidowicz, 2005, s. 235).

Przełomowym rokiem dla rynku funduszy inwestycyjnych był 1997 r. utworzono 15 nowych funduszy, w tym pierwszy fundusz rynku pieniężnego i gotówkowy. Na koniec roku aktywnie działało 20 funduszy (8 akcyjnych, 3 obligacji, 7 zrównoważonych i 2 rynku pieniężnego), którymi zarządzało 7 TFI. Najwięcej aktywów zgromadzonych było w funduszach zrównoważonych (61\% aktywów ogółem na koniec 1997 r.). Drugą największą grupa były fundusze akcyjne (35\% aktywów ogółem), co wynikało z pozytywnej koniunktury na warszawskiej giełdzie (lata 1996-1997), która przełożyła się na wysokie stopy zwrotu funduszy akcyjnych (Perez, 2012, s. 171). W ramach funduszy akcyjnych pojawiły się również fundusze prywatyzacji, które inwestowały w akcje NFI i powszechne świadectwa udziałowe (Parczewski, 2001).

Dominującą pozycję w latach 1992-1997 zajmowało towarzystwo Pioneer Pekao, którego udział w rynku na koniec 1997 r. wynosił ponad 80\%.

\section{ETAP 2 - PRZEKSZTAŁCENIE FUNDUSZY POWIERNICZYCH W INWESTYCYJNE (STYCZEŃ 1998-GRUDZIEŃ 2000)}

Uchwalona w sierpniu $1997 \mathrm{r}$. ustawa o funduszach inwestycyjnych weszła w życie dopiero w lutym 1998 r. Długi okres wprowadzenia nowej ustawy wynikał ze znaczących zmian zawartych w tym akcie prawnym. Najważniejszą $\mathrm{z}$ nich było zlikwidowanie funduszy powierniczych i wprowadzenie $\mathrm{w}$ ich miejsce funduszy inwestycyjnych. Istniejące fundusze powiernicze mogły prowadzić działalność na dotychczasowych zasadach jeszcze przez 3 lata albo przekształcić się w fundusze inwestycyjne otwarte. Ustawa ta wprowadziła szereg zmian w zakresie funkcjonowania funduszy (najważniejsze różnice przedstawiono w tabeli 2).

\footnotetext{
${ }^{2}$ W 1993 r. nowelizacja ustawy (ustawa z 29 grudnia 1993 r.) rozszerzyła kanały dystrybucji o domy maklerskie i inne podmioty za zgodą KPWiG.
} 
Tabela 2. Porównanie funduszy powierniczych i inwestycyjnych

\begin{tabular}{|c|c|c|}
\hline Cecha & Fundusz powierniczy & Fundusz inwestycyjny \\
\hline Forma prawna & $\begin{array}{l}\text { Wyodrębniona masa } \\
\text { majatkowa bez osobo- } \\
\text { wości prawnej }\end{array}$ & Osoba prawna \\
\hline $\begin{array}{l}\text { Konstrukcja prawna } \\
\text { funduszu }\end{array}$ & fundusz powierniczy & $\begin{array}{c}\text { - fundusz inwestycyjny otwarty (FIO), } \\
\text { - specjalistyczny fundusz inwestycyjny otwar- } \\
\text { ty (SFIO), } \\
\text { - fundusz inwestycyjny zamknięty (FIZ), } \\
\text { - fundusz inwestycyjny mieszany (FIM) }\end{array}$ \\
\hline Cel inwestycyjny & $\begin{array}{l}\text { Zgodnie z regulaminem } \\
\text { funduszu; brak możli- } \\
\text { wości zmiany celu } \\
\text { w trakcie funkcjonowa- } \\
\text { nia funduszu }\end{array}$ & $\begin{array}{l}\text { - ochrona realnej wartości aktywów funduszu, } \\
\text { - osiaganie dochodu z lokowania aktywów } \\
\text { funduszu. } \\
\text { - wzrost wartości aktywów funduszu w wyniku } \\
\text { wzrostu wartości lokat }\end{array}$ \\
\hline Katalog lokat & $\begin{array}{l}\text { Tylko papiery warto- } \\
\text { ściowe }\end{array}$ & Zależny od rodzaju funduszu \\
\hline $\begin{array}{l}\text { Dywersyfikacja portfela } \\
\text { inwestycyjnego }\end{array}$ & Bardzo niska & Raczej wysoka \\
\hline $\begin{array}{l}\text { Dystrybucja dochodu } \\
\text { funduszu }\end{array}$ & $\begin{array}{l}\text { Brak, dochody powięk- } \\
\text { szaja aktywa funduszu }\end{array}$ & $\begin{array}{l}\text { Powiększenie aktywów funduszu lub dystry- } \\
\text { bucja }\end{array}$ \\
\hline
\end{tabular}

Źródło: opracowanie własne na podstawie ustawy z 22 marca 1991 r. oraz ustawy z 28 sierpnia $1997 \mathrm{r}$.

Zmianą o największym znaczeniu dla rynku funduszy inwestycyjnych było rozszerzenie katalogu dopuszczalnych lokat oraz wprowadzenie różnych rodzajów funduszy. FIO i SFIO, podobnie jak fundusze powiernicze, mogły lokować aktywa w papiery wartościowe. Dodatkowo dopuszczone było lokowanie maksymalnie 5\% aktywów w jednostki uczestnictwa innych funduszy inwestycyjnych (krajowych i zagranicznych). Z kolei FIM charakteryzowały się większą swobodą kształtowania strategii inwestycyjnych aktywa funduszu mogły być lokowane w papiery wartościowe, wierzytelności, udziały w spółkach $\mathrm{z}$ ograniczoną odpowiedzialnością i waluty (ustawa z 28 sierpnia 1997 r.). FIZ mogły inwestować dodatkowo w prawa pochodne od praw majątkowych będących przedmiotem lokat i transakcje terminowe.

Pierwsze fundusze inwestycyjne rozpoczęły funkcjonować na początku 1999 r., czyli prawie rok od momentu wprowadzenia ustawy o funduszach inwestycyjnych, na co wpływ miał przede wszystkim proces przekształcania towarzystw funduszy powierniczych $w$ towarzystwa funduszy inwestycyjnych i funduszy powierniczych w FIO. Dodatkowo na rozpatrzenie przez KPWiG oczekiwało 41 wniosków o utworzenie funduszy powierniczych złożonych jeszcze w 1997 r. (Jarosz, 1997). W 1998 r. TFI wykorzystały nowe możliwości dystrybucji tytułów uczestnictwa - PKO/Credit Suisse 
uzyskało zgodę KPWiG na dystrybucję jednostek uczestnictwa w funduszach inwestycyjnych za pośrednictwem oddziałów PKO Bank Polski i ING w oddziałach banku ING, Skarbiec wprowadził telefoniczną obsługę zleceń i jako pierwsze TFI uruchomiło sprzedaż jednostek uczestnictwa przez firmę ubezpieczeniową (Hestia). Z kolei Pioneer Pekao umożliwił nabywanie jednostek uczestnictwa funduszy za pomocą przelewu (Miziołek, 1998, s. 72). We wrześniu 2000 r. drugie towarzystwo ubezpieczeniowe (Scandia Życie) rozpoczęła współpracę z TFI przy dystrybucji jednostek uczestnictwa. W przeciwieństwie do Hestii, w ofercie Scandia Życie znalazło się 21 funduszy różnych TFI.

Nowością na rynku były fundusze akcyjne lokujące aktywa na rynkach zagranicznych (4 fundusze), gwarantowane ( 2 fundusze) $)^{3}$ i dywidendowe (19 funduszy $)^{4}$. Najważniejszymi z nowych rozwiązań były skierowane do inwestorów instytucjonalnych fundusze dywidendowe, zapewniające wypłatę zysków w formie dywidendy od dochodów funduszu (bez konieczności umarzania jednostek uczestnictwa), która była opodatkowana zryczałtowanym podatkiem w wysokości $20 \%$ (zamiast $30 \%$ ). Do tego podatek ten mógł być później odliczany od podatku dochodowego (Perez, 2012, s. 174). Fundusze te funkcjonowały głównie jako fundusze rynku pieniężnego i gotówkowe. W 1998 r. wartość aktywów tych funduszy wzrosła z $15 \mathrm{mln}$ do $158 \mathrm{mln} \mathrm{zł}$.

Proces przekształcania funduszy powierniczych w FIO został zakończony w 2000 r. Struktura przedmiotowa rynku kształtowała się następująco: 25 funduszy akcyjnych, 16 obligacji (w tym 1 dywidendowy), 15 rynku pieniężnego i gotówkowe (w tym 6 dywidendowych), 14 zrównoważonych, 9 stabilnego wzrostu i 2 gwarantowane. Uwzględniając kryterium formy prawnej, w 2000 r. było: 61 FIO, 17 SFIO (z czego 9 rozpoczęło działalność już w 1999 r.) i 2 FIZ (z czego 1 utworzono w 1999 r.) (STFI, 2001, s. 6). Aktywa 80 funduszy wzrosły ponad dwukrotnie w stosunku do 1999 r. i wynosiły ponad $7 \mathrm{mld}$ zł, z czego prawie połowa była ulokowana w funduszach rynku pieniężnego i gotówkowych, co wynikało z funkcjonowania 6 funduszy dywidendowych w tym segmencie rynku funduszy inwestycyjnych i skierowania do nich znacznej części kapitałów inwestorów instytucjonalnych (3 mld zł). Zmiany oferty produktowej TFI dotknęły najbardziej fundu-

\footnotetext{
${ }^{3}$ Fundusze gwarantowane funkcjonowały jako fundusze zamknięte. Zapewniały posiadaczom wypłatę minimalnej wartości certyfikatu inwestycyjnego w terminie likwidacji funduszu (Miziołek, 2001, s. 70).

${ }^{4}$ Funkcjonujące od $1997 \mathrm{r}$. fundusze prywatyzacji ze względu na uzyskiwanie coraz niższych stóp zwrotu zmieniły strategie inwestycyjne.
} 
sze zrównoważone, których udział zaledwie w 3 lata zmniejszył się o ponad połowę (z $51 \%$ do $22 \%$ ).

Wprowadzone przez TFI zmiany spowodowały zmniejszenie udziału Pioneer Pekao w rynku prawie o połowę (do 43\% w 1999 r.). W kolejnym roku nastąpiło dalsze zmniejszenie koncentracji - w 2000 r. najwięcej aktywów zgromadzonych było w Skarbcu (36\% udziału w rynku), Pioneer Pekao (17\%) i DWS Polska (12\%).

Tabela 3. Liczba i aktywa funduszy powierniczych i inwestycyjnych w okresie 1998-2000

\begin{tabular}{cccc}
\hline Rok & 1998 & 1999 & 2000 \\
\hline Liczba towarzystw funduszy powierniczych i inwestycyjnych & 12 & 15 & 20 \\
Liczba funduszy, w tym: & 38 & 65 & 80 \\
fundusze powiernicze & 38 & 12 & 0 \\
fundusze inwestycyjne & bd & 50 & 80 \\
Aktywa funduszy (w mld zł), w tym (w \%): & 1,8 & 3,2 & 7,2 \\
akcyjnych & 28 & 24 & 15 \\
obligacji & 14 & 28 & 17 \\
zrównoważone i stabilnego wzrostu & 51 & 39 & 22 \\
rynku pieniężnego i gotówkowe & 7 & 9 & 46 \\
\hline
\end{tabular}

Źródło: obliczenia i opracowanie własne na podstawie STFI i KPWG.

\section{ETAP 3 - FUNDUSZE INWESTYCYJNE \\ W OKRESIE STYCZEŃ 2001-GRUDZIEŃ 2004}

Nowelizacja ustawy o podatku dochodowym od osób prawnych z 9 czerwca 2000 r., która weszła w życie 1 stycznia 2001 r., zlikwidowała korzyści podatkowe funduszy dywidendowych (Przybylska-Kapuścińska $\mathrm{i}$ inni, 2004, s. 376). TFI zastapily te fundusze funduszami terminowymi (przekształcono 11 z 19 funduszy). Były to FIZ lub FIM z określoną datą likwidacji i umożliwiające osobom prawnym zbycie certyfikatów inwestycyjnych przed zakończeniem działalności funduszu. Zyski z tych inwestycji były opodatkowane zryczałtowanym podatkiem w wysokości 15\%.

Nowelizację ustawy o funduszach inwestycyjnych, której celem było dostosowanie polskiego prawa do prawa Unii Europejskiej, uchwalono 16 listopada $2000 \mathrm{r}$. Tabela 4 zawiera najważniejsze zmiany wynikające $\mathrm{z}$ tej nowelizacji ustawy. 
Tabela 4. Najważniejsze zmiany wprowadzone przez ustawę z 16 listopada $2000 \mathrm{r}$.

\begin{tabular}{cc}
\hline Ustawa z $1997 \mathrm{r}$. & Ustawa z 2000 r. \\
\hline $\begin{array}{c}\text { Wpłaty do funduszu dokonywane sa w go- } \\
\text { tówce i papierach wartościowych dopuszczo- } \\
\text { nych do publicznego obrotu }\end{array}$ & $\begin{array}{c}\text { Rozszerzenie o papiery wartościowe niedopusz- } \\
\text { czone do publicznego obrotu i udziały w spółkach } \\
\text { z ograniczona odpowiedzialnością }\end{array}$ \\
\hline $\begin{array}{c}\text { Fundusz inwestycyjny może być utworzony } \\
\text { jako: FIO, SFIO, FIZ i FIM }\end{array}$ & $\begin{array}{c}\text { Dodanie nowego rodzaju funduszu - specjalistycz- } \\
\text { nego funduszu zamkniętego (SFIZ) i rozszerzenie } \\
\text { katalogu lokat }\end{array}$ \\
$\begin{array}{c}\text { Fundusz może zbywać tytuły uczestnictwa za } \\
\text { pośrednictwem domów maklerskich i innych } \\
\text { podmiotów za zgodą KPWiG }\end{array}$ & $\begin{array}{c}\text { Rozszerzenie kanałów dystrybucji o osoby fizyczne } \\
\text { oraz elektroniczne nośniki informacji (m.in. Internet) }\end{array}$ \\
\hline
\end{tabular}

Źródło: opracowanie własne na podstawie ustawy z 28 sierpnia 1997 r. oraz ustawy z 16 listopada $2000 \mathrm{r}$.

Nowelizacja wprowadziła również:

- możliwość zarządzania zbiorczym portfelem papierów wartościowych,

- możliwość łączenia FIO i SFIO,

- możliwość wystapienia jednocześnie o wydanie zezwolenia na działalność towarzystwa funduszy inwestycyjnych i utworzenie funduszy ${ }^{5}$.

Wprowadzony nowy rodzaj funduszu, SFIZ, w przeciwieństwie do FIZ mógł emitować certyfikaty inwestycyjne niedopuszczone do publicznego obrotu i w porównaniu do innych rodzajów funduszy mógł lokować aktywa tylko w prawa własności do nieruchomości gruntowych, budynków i odrębnych lokali oraz w udziały we współwłasności nieruchomości. Niepubliczne certyfikaty musiały spełniać jeden z dwóch warunków: być skierowane do nie więcej niż 300 inwestorów lub ich wartość nominalna nie mogła być niższa niż 40000 euro. Wszystkie rodzaje funduszy (z wyłączeniem SFIZ) uzyskały możliwość lokowania środków w hipoteczne listy zastawne (do $25 \%$ aktywów funduszu w listy wyemitowane przez jeden bank). FIZ dodatkowo mogły inwestować w tytuły uczestnictwa krajowych i zagranicznych funduszy inwestycyjnych. Wykluczenie hipotecznych listów zastawnych z dopuszczalnego katalogu lokat można wytłumaczyć obawą ustawodawcy o możliwość pojawienia się konfliktu interesów między bankiem udzielającym kredytów zabezpieczonych nieruchomościami a funduszem, który był ich właścicielem.

Rozpoczęta w 2000 r. zmiana kanałów dystrybucji tytułów uczestnictwa $\mathrm{w}$ funduszach inwestycyjnych (wprowadzenie sprzedaży funduszy do ban-

\footnotetext{
${ }^{5}$ Do czasu nowelizacji ustawy wniosek o wydanie zezwolenia na działalność funduszu mogły złożyć tylko TFI, co w praktyce wydłużało okres rozpoczęcia funkcjonowania funduszu.
} 
ków, firm doradztwa finansowego i ubezpieczeniowych ${ }^{6}$ oraz przez Internet) wpłynęła na zwiększenie aktywów funduszy na koniec 2001 r. do $12 \mathrm{mld}$ zł (wzrost o $5 \mathrm{mld}$ w stosunku do poprzedniego roku). Na osiagnięty wynik wpływ miały również: zmiany wprowadzone przez nowelizację ustawy o funduszach inwestycyjnych z 2000 r., spadająca rentowność depozytów bankowych, zaplanowane na 2002 r. wprowadzenie opodatkowania zysków kapitałowych i zwiększone zainteresowanie funduszami ze strony klientów indywidualnych. W grudniu $2001 \mathrm{r}$. funkcjonowało $19 \mathrm{TFI}$, w tym jedno towarzystwo (ABN Amro) rozpoczęło proces likwidacji i jedno nie zarządzało żadnym funduszem. Towarzystwa zarządzały łącznie 94 funduszami, w tym 26 funduszami akcyjnymi, 19 funduszami obligacji, 31 funduszami zrównoważonymi i stabilnego wzrostu oraz 18 funduszami rynku pieniężnego i gotówkowymi. Według konstrukcji prawnej najliczniej reprezentowane były FIO (72 fundusze). Pozostałe fundusze - SFIO (23), FIZ (4) i SFIZ (1).

Tabela 5. Liczba i aktywa aktywnych funduszy powierniczych i inwestycyjnych w okresie 2001-2004

\begin{tabular}{ccccc}
\hline Rok & 2001 & 2002 & 2003 & 2004 \\
\hline Liczba towarzystw funduszy inwestycyjnych & 19 & 20 & 17 & 19 \\
Liczba funduszy inwestycyjnych & 94 & 112 & 121 & 144 \\
Aktywa funduszy (w mld zł), w tym (w \%): & 12,1 & 23,0 & 33,5 & 36,9 \\
akcyjnych & 9 & 5 & 7 & 14 \\
obligacji & 56 & 67 & 50 & 32 \\
zrównoważone i stabilnego wzrostu & 15 & 8 & 24 & 36 \\
rynku pieniężnego i gotówkowe & 20 & 18 & 16 & 14 \\
pozostałe & 0 & 2 & 3 & 4 \\
\hline
\end{tabular}

Liczba TFI i funduszy oraz aktywa pochodzą z danych KNF. Udział poszczególnych typów funduszy pochodzi z danych IZFiA.

Źródło: obliczenia i opracowanie własne na podstawie danych KNF i IZFiA.

Następne 2 lata były zdominowane przez fundusze „antypodatkowe” i obligacji (2002 r.) oraz fundusze akcyjne (2003 r.). Wprowadzenie w marcu 2002 r. podatku od zysków kapitałowych i 8 obniżek stóp procentowych w całym roku spowodowało przesunięcie znacznej części wycofanych środków z depozytów bankowych do funduszy inwestycyjnych. Największy przyrost aktywów zanotowały fundusze obligacji, co wynikało z dużego zainteresowania polskimi obligacjami ze strony inwestorów zagranicznych i znaczącym spadkiem poziomu inflacji w krótkim okresie czasu. $Z$ kolei za-

\footnotetext{
${ }^{6}$ Generali Życie TU wprowadziło do swojej oferty ubezpieczenie na życie z funduszem inwestycyjnym TFI Skarbiec. Podobny produkt zaproponował MetLife Amplico - ubezpieczenie na życie z 6 funduszami inwestycyjnymi 3 TFI (Miziołek, 2001, s. 71-72).
} 
oferowane przez TFI fundusze ,antypodatkowe” były odpowiedzią na tzw. podatek Belki i korzystały ze zwolnienia (do końca 2003 r.) z podatku od zysków ze sprzedaży certyfikatów inwestycyjnych na giełdzie. W przeciwieństwie do funduszy dywidendowych skierowane były zarówno do inwestorów indywidualnych, jak i instytucjonalnych. Fundusze ,,antypodatkowe” (9), z terminem likwidacji czerwiec-grudzień 2003 r., zgromadziły łącznie ponad 1,9 mld zł (z planowanych 2,7 mld zł) (Siwek, 2003, 2004). Z kolei niepowodzeniem zakończyła się subskrypcja na pierwszy w historii rynku fundusz nieruchomości (Skarbiec Sektora Nieruchomości). Fundusz ten planował zgromadzić aktywa w wysokości 30-150 mln zł przy cenie certyfikatu inwestycyjnego na poziomie $100 \mathrm{zł}$. W skład lokat miały wchodzić grunty budowlane i rolne $\mathrm{z}$ możliwością przekształcenia w budowlane. Okres zapisów na certyfikaty inwestycyjne tego funduszu zbiegł się w czasie z wysokim zainteresowaniem inwestorów indywidualnych FIO (głównie funduszami obligacji) i zapotrzebowaniem na fundusze terminowe ze strony inwestorów instytucjonalnych.

Powodzenie pierwszych funduszy ,antypodatkowych” zachęciło TFI do zaproponowania kolejnych. Pod koniec 2003 r. TFI utworzyły 13 nowych funduszy ,antypodatkowych” $\mathrm{z}$ ofertą na ponad $5 \mathrm{mld} \mathrm{zł.} \mathrm{Z} \mathrm{zainteresowa-}$ niem inwestorów spotkało się tylko 8 funduszy, które zgromadziły 0,5 mld zł (Przybylska-Kapuścińska i inni, 2004, s. 382). Przyczyn niepowodzenia drugiej fali funduszy ,antypodatkowych” należy upatrywać w wysokich kosztach manipulacyjnych i niższych stopach zwrotu od oczekiwanych - średnia stopa zwrotu tych funduszy wynosiła 5\%, a funduszy akcyjnych 23\% (po opodatkowaniu) (Siwek, 2003b). Uzyskane wyniki funduszy ,antypodatkowych” (aktywa lokowane głównie w obligacje) i funduszy akcyjnych wynikały z zakończenia hossy na rynku obligacji i początkiem hossy na rynku akcji (2003 r.). Nie doszła do skutku również druga próba utworzenia funduszu nieruchomości (CA IB Sektora Nieruchomości). Polityka tego funduszu zakładała inwestycje w akcje i papiery dłużne emitowane przez spółki prowadzące działalność na rynku nieruchomości. Niepowodzenie emisji spowodowane było wysokimi kosztami manipulacyjnymi i zbyt krótkim okresem zapisów na certyfikaty inwestycyjne. Dodatkowym czynnikiem blokującym powstawanie funduszy nieruchomości były niejednoznaczne przepisy prawne - zgodnie z obowiązującym prawem fundusze inwestycyjne mogły lokować aktywa w nieruchomości wolne od obciążeń, w tym prawami osób trzecich. Taki zapis powodował, że przedmiotem lokat funduszu nie mogły być nieruchomości z ograniczonymi prawami rzeczowymi (np. z prawem przechodu) czy w użytkowaniu wieczystym, co z kolei dyskwalifikowało prawie wszystkie polskie nieruchomości. 
W maju 2004 r. zmieniono po raz czwarty obowiązujące przepisy. Wprowadzenie nowej ustawy o funduszach inwestycyjnych (ustawa z 27 maja 2004 r.) wynikało z dostosowania obowiązujących przepisów do prawa wspólnotowego ${ }^{7}$. Kluczową zmianą wprowadzoną przez ten akt prawny było zlikwidowanie FIM i SFIZ ${ }^{8}$ oraz wprowadzenie 3 szczególnych konstrukcji i 4 szczególnych typów funduszy inwestycyjnych. W ramach pierwszej grupy wprowadzono fundusze: $\mathrm{z}$ różnymi kategoriami jednostek uczestnictwa (różniącymi się od siebie wysokością opłat manipulacyjnych lub sposobem zarządzania), z wydzielonymi subfunduszami (tzw. parasolowe), podstawowe i powiązane. W drugiej grupie wyróżniono następujące fundusze: rynku pieniężnego, portfelowe, sekurytyzacyjne i aktywów niepublicznych (FIZAN). Drugą istotną zmianą dla rynku funduszy inwestycyjnych było podniesienie limitu pojedynczej transakcji zakupu nieruchomości do $25 \%$ aktywów funduszu oraz możliwość nabywania obiektów i gruntów obarczonych prawami na rzecz osób trzecich. Jeszcze przed wejściem w życie nowej ustawy BZ WBK rozpoczął subskrypcję na certyfikaty Arki Funduszu Rynku Nieruchomości. Polityka tego funduszu zakładała inwestycje w biurowce, mieszkania oraz akcje i udziały spółek funkcjonujących na rynku nieruchomości. Emisja certyfikatów inwestycyjnych doszła do skutku i Arka Fundusz Rynku Nieruchomości rozpoczął funkcjonowanie jako pierwszy polski fundusz nieruchomości (sprzedano certyfikaty na łączną kwotę 339,5 mln zł przy cenie jednostkowej certyfikatu 97 zł). We wrześniu $2004 \mathrm{r}$. rozpoczął funkcjonowanie drugi fundusz lokujący aktywa na rynku nieruchomości - Skarbiec Fundusz Rynku Nieruchomości FIZ. Fundusz ten zakłada inwestycje w budownictwo mieszkaniowe. Fundusz zgromadził $87,43 \mathrm{mln}$ zł, przy cenie jednostkowej certyfikatu $1000 \mathrm{zl}$. Zmienione zostały również limity i możliwości inwestycyjne SFIO. Ustawodawca dopuścił możliwość lokowania do 100\% aktywów w tytuły uczestnictwa krajowych FIO i zagranicznych funduszy inwestycyjnych (tzw. fundusze funduszy). Z nowych możliwości skorzystały 3 TFI - BZ WBK i Skarbiec otworzyły po jednym funduszu nieruchomości, a $\mathrm{KBC}-4$ fundusze $\mathrm{z}$ ochroną kapitału. $\mathrm{Z}$ kolei pierwsze fundusze funduszy ${ }^{9}$ powstały dopiero w $2005 \mathrm{r}$.

\footnotetext{
${ }^{7}$ Ustawa wprowadziła także możliwość sprzedawania w Polsce tytułów uczestnictwa funduszy zagranicznych. Szerzej w Miziołek (2005).

${ }^{8}$ Fundusze te miały prawny obowiązek przekształcenia w FIZ do końca czerwca $2005 \mathrm{r}$. (Dawidowicz, 2008, s. 36).

${ }^{9}$ Szerzej w Królik (2011).
} 


\section{ETAP 4 - FUNDUSZE INWESTYCYJNE W OKRESIE STYCZEŃ 2005-GRUDZIEŃ 2011}

Możliwość tworzenia jednego funduszu $\mathrm{z}$ wieloma subfunduszami o odmiennych politykach inwestycyjnych spotkała się z ogromnym zainteresowaniem ze strony inwestorów. Niewątpliwie spowodowane to było korzyściami podatkowymi (podatek od zysków jest naliczany dopiero w momencie umorzenia tytułów uczestnictwa w funduszu, a transfer środków między subfunduszami w ramach jednego funduszu jest zwolniony z podatku od zysków kapitałowych). Pod koniec 2004 r. istniały tylko 3 fundusze parasolowe, a pod koniec 2011 r. już 56. Najwięcej przekształceń funduszy w subfundusze miało miejsce w 2007 r. i 2008 r. (odpowiednio 82 i 87). Z małym zainteresowaniem spotkały się fundusze podstawowe i powiązane oraz portfelowe. Pierwsze dwa fundusze podstawowe i powiązane pojawiły się w 2006 r. i funkcjonowały do grudnia 2011 r. jako jedyne tego typu. Z kolei fundusze portfelowe zostały utworzone dopiero w $2010 \mathrm{r}$. (3 fundusze) i do końca następnego roku ich liczba nie uległa zmianie. Wolniej od założeń rozwijały się fundusze sekurytyzacyjne - pierwsze 3 fundusze powstały w 2005 r. z inicjatywy firm windykacyjnych. Pod koniec 2009 r. funkcjonowało 21 funduszy sekurytyzacyjnych $\mathrm{z}$ niewielkim udziałem w aktywach wszystkich funduszy. W następnym roku nie rozpoczął działalności ani jeden fundusz sekurytyzacyjny. A w 2011 r. powstało ich aż 10, zwiększając liczbę tych funduszy do 31 (udział w rynku $1,4 \%)^{10}$.

Wprowadzenie funduszy rynku pieniężnego spowodowało przekształcenie większości istniejących funduszy pieniężnych i gotówkowych w ten typ funduszy, co pozwoliło na zwiększenie aktywów netto tej grupie funduszy z 7,5 mld zł w 2005 r. do 20 mld zł na koniec 2011 r. Dodatkowo Superfund utworzył fundusze $\mathrm{z}$ polityką inwestycyjną charakterystyczną dla funduszy hedge. Należy także zwrócić uwagę na fundusze nieruchomości - TFI wykorzystały panującą na rynku nieruchomości bessę w 2008 r. i utworzyły aż 7 nowych funduszy lokujących aktywa na tym rynku. W następnych latach przybywały kolejne fundusze nieruchomości, zwiększając liczbę tej grupy na koniec 2011 r. do 27 (prawie 3\% udział w rynku funduszy inwestycyjnych).

Spowolnienie gospodarcze, które rozpoczął kryzys finansowy z 2007 r., wpłynęło na rynek funduszy inwestycyjnych w Polsce dopiero w 2008 r. Wartość aktywów netto wszystkich funduszy zmniejszyła się prawie dwukrotnie. Najwięcej straciły fundusze związane z akcjami - zrównoważone ponad $40 \mathrm{mld} \mathrm{zł}$ i akcyjne ponad $25 \mathrm{mld} \mathrm{zł}$, co spowodowane było głównie przez koniec hossy na warszawskiej giełdzie. Natomiast w 2007 r. TFI utwo-

\footnotetext{
${ }^{10}$ Szerzej w Potoczek (2011).
} 
rzyły rekordową liczbę funduszy i subfunduszy w całej historii rynku (łącznie 122 FIO i SFIO oraz 51 FIZ i FIZAN). Był to również ostatni rok, gdy liczba FIO i SFIO była wyższa niż liczba FIZ ${ }^{11}$.

W kolejnych latach (2009-2011) wartość aktywów netto funduszy inwestycyjnych zwiększała się pomimo zmiennych warunków gospodarczych. $\mathrm{Na}$ koniec $2011 \mathrm{r}$. fundusze inwestycyjne zarządzały aktywami netto o wartości prawie 126 mld zł. Najwięcej środków zgromadzonych było w funduszach związanych z akcjami (fundusze akcyjne, zrównoważone i stabilnego wzrostu - łącznie $50 \mathrm{mld}$ zł) i dłużnymi papierami wartościowymi (fundusze rynku pieniężnego i obligacji - łącznie $41 \mathrm{mld}$ zł).

Tabela 6. Liczba i aktywa aktywnych funduszy powierniczych i inwestycyjnych w okresie 2005-2011

\begin{tabular}{|c|c|c|c|c|c|c|c|}
\hline Rok & 2005 & 2006 & 2007 & 2008 & 2009 & 2010 & 2011 \\
\hline $\begin{array}{l}\text { Liczba towarzystw funduszy } \\
\text { inwestycyjnych }\end{array}$ & 23 & 26 & 33 & 39 & 43 & 50 & 51 \\
\hline Liczba funduszy, w tym: & 190 & 229 & 277 & 318 & 369 & 417 & 473 \\
\hline FIZ i FIZAN & 34 & 62 & 103 & 175 & 226 & 300 & 360 \\
\hline fundusze parasolowe & 7 & 14 & 25 & 34 & 43 & 50 & 56 \\
\hline Liczba subfunduszy & 27 & 47 & 129 & 216 & 249 & 297 & 331 \\
\hline $\begin{array}{l}\text { Aktywa funduszy (w mld zł), } \\
\qquad w \operatorname{tym}(w \%):\end{array}$ & 61,4 & 101,6 & 142,2 & 81,5 & 104,5 & 134,3 & 125,9 \\
\hline akcyjnych & 11,8 & 21,4 & 31,3 & 23,4 & 29,1 & 27,6 & 19,1 \\
\hline obligacji & 24,6 & 10,0 & 6,5 & 15,3 & 13,6 & 14,4 & 17,3 \\
\hline zrównoważone i stabilnego wzrostu & 44,8 & 52,4 & 49,0 & 35,4 & 32,6 & 29,1 & 21,2 \\
\hline rynku pieniężnego & 12,2 & 7,6 & 6,5 & 10,3 & 9,3 & 13,2 & 16,1 \\
\hline nieruchomości & 1,3 & 1,2 & 1,1 & 3,0 & 2,6 & 2,0 & 2,7 \\
\hline sekurytyzacyjne & 0,2 & 0,5 & 0,5 & 1,2 & 1,0 & 0,7 & 1,4 \\
\hline aktywów niepublicznych & 0,0 & 0,0 & 2,0 & 6,6 & 8,0 & 9,7 & 19,6 \\
\hline pozostałe & 5,1 & 6,9 & 3,1 & 4,8 & 3,8 & 3,3 & 2,6 \\
\hline
\end{tabular}

Liczba TFI i funduszy oraz aktywa pochodzą z danych KNF. Udział poszczególnych typów funduszy pochodzi z danych IZFiA i sprawozdań finansowych funduszy nieruchomości.

Źródło: obliczenia i opracowanie własne na podstawie danych IZFiA i KNF.

Obniżenie wymaganego kapitału zakładowego dla TFI z $3 \mathrm{mln}$ zł do 125 tys. Euro otworzyło ten rynek dla nowych firm. Obok towarzystw powiązanych z bankami, grupami ubezpieczeniowymi i zagranicznymi instytucjami asset management pojawiły się TFI, których akcjonariuszami zostały osoby z wieloletnim doświadczeniem w zarządzaniu aktywami. Pierwszymi

${ }^{11}$ W 2008 r. KNF udzielił zezwoleń na utworzenie 11 FIO i SFIO oraz 81 subfunduszy, 82 FIZ i FIZAN oraz 9 subfunduszy FIZ. W całym 2011 r. TFI uruchomily tylko 52 FIO i SFIO oraz 85 FIZ i FIZAN. 
„nowymi” towarzystwami były Opera i Investors (oba towarzystwa założone przez zespoły specjalistów, którzy zarządzali funduszami w innych TFI) oraz Intrum Justitia TFI (założone przez zagraniczną firmę zarządzającą należnościami). W kolejnych latach powstały towarzystwa zarządzające zarówno funduszami dedykowanymi określonym grupom inwestorów prywatnych i instytucjonalnych, m.in. Hexagon, BDM, KGHM, jak i funduszami o wyspecjalizowanej polityce inwestycyjnej, m.in. Agro zarządzające funduszem inwestującym $\mathrm{w}$ grunty rolne $\mathrm{i}$ następnie wydzierżawiane rolnikom.

W latach 2005-2011 KNF udzielił zezwoleń na prowadzenie działalności 31 nowych towarzystw, w tym 2 związane $\mathrm{z}$ grupą bankowa, $1 \mathrm{z}$ austriackim TFI (Superfund) i $1 \mathrm{z}$ grupą ubezpieczeniową (AXA) ${ }^{12}$. Większość pozostałych TFI zostało utworzonych przez polskie firmy specjalizujące się w doradztwie inwestycyjnym. Bardzo widoczny jest spadek udziału banków w tworzeniu nowych TFI i „zamawianiu” przez nie funduszy. Banki nieposiadające w grupie kapitałowej TFI, głównie ze względów ekonomicznych i brak know how, decydują się na przygotowanie i zarządzanie funduszami przez „obce” TFI. Takie fundusze (nazywane white label lub private label) realizują politykę inwestycyjną przygotowaną przez bank i działają pod jego marką. Ipopema TFI w 2011 r. zarządzało funduszami stworzonymi dla Alior Banku (1 fundusz z 4 subfunduszami), TFI Skarbiec zarząadzało funduszami inwestycyjnymi Multibanku i mBanku (po 2 fundusze) oraz BZ WBK funduszami Credit Agricole (1 fundusz z 5 subfunduszami).

Kluczowe zmiany nastapiły w sposobie dystrybucji tytułów uczestnictwa funduszy inwestycyjnych. W lipcu 2003 r. Multibank i mBank uruchomiły platformy internetowe umożliwiające zakup funduszy różnych TFI (Multibank, 2012). W tym samym roku KNF wydał zgodę na dystrybucję funduszy przez dwóch ogólnopolskich pośredników, zwiększając liczbę dystrybutorów niebędących domami maklerskimi i bankami do 11. Na koniec $2011 \mathrm{r}$. fundusze były dystrybuowane przez 74 podmioty. Druga ważna zmiana zaszła w dystrybucji funduszy przez banki. Do 2008 r. banki oferowały (poza Multibankiem i mBankiem) fundusze TFI ze swoich grup kapitałowych. W kolejnych latach następowało rozszerzanie oferty bankowej o fundusze innych TFI. Najwięcej TFI oferuje Multibank (19), mBank (18) i Deutsche Bank (12). A najczęściej dystrybuowanymi funduszami są Skarbiec i Union Investment (11 banków), Aviva (9) i Investors (8). W dystrybucji znajdują

\footnotetext{
${ }^{12}$ Zwiększenie liczby TFI w latach 2005-2011 pozytywnie wpłynęło na wzrost konkurencji między towarzystwami. Na koniec 2011 r. 3 dominujące TFI posiadały poniżej $30 \%$ udziałów (spadek o 20 p.p. porównaniu do grudnia 2004 r.).
} 
się głównie FIO. SFIO i FIZ są dostępne w nielicznych bankach i w ograniczonym zakresie, np. Multibank w ofercie ma 4 (w tym 1 fundusz nieruchomości) i mBank - 2 (2 fundusze nieruchomości).

\section{PODSUMOWANIE}

Determinanty prawno-podatkowe mają znaczący i ograniczony wpływ na strukturę rynku funduszy inwestycyjnych. Przepisy prawne reguluja ogólne zasady działania funduszy inwestycyjnych (w tym dopuszczalne składowe portfeli inwestycyjnych i możliwe rodzaje funduszy), co szczególnie było widoczne po wprowadzeniu ustawy o funduszach inwestycyjnych w 2004 r. Zwiększenie dopuszczalnego katalogu lokat umożliwiło zaistnienie funduszy ze specjalistycznymi politykami inwestycyjnymi (m.in. fundusze nieruchomości i sekurytyzacyjne). Zmiany przepisów prawa przyczyniły się także do zwiększenia kanałów dystrybucji tytułów uczestnictwa w funduszach inwestycyjnych, a tym samym do zwiększenia dostępności tych instrumentów finansowych. $Z$ kolei determinanta podatkowa wpływa obecnie tylko na część rynku funduszy inwestycyjnych - na fundusze zamknięte, które umożliwiają inwestorom instytucjonalnym korzystanie ze zwolnień podatkowych.

Uwzględniając udział różnych typów funduszy inwestycyjnych w całym rynku, można zauważyć przyzwyczajenie inwestorów do tradycyjnych funduszy (akcyjnych, obligacji, zrównoważonych i stabilnego wzrostu oraz rynku pieniężnego), w których jest ulokowane ponad 70\% aktywów netto wszystkich funduszy (stan na koniec 2011 r.). Z kolei inwestorzy instytucjonalni wybierają FIZAN, które zarządzają 1/5 aktywów całego rynku.

\section{LITERATURA}

Dawidowicz D. (2005), Rozwój funduszy inwestycyjnych na polskim rynku kapitałowym, [w:] Karpuś P., Węcławski J (red.), Przekształcenia rynku finansowego w Polsce, Wydawnictwo Uniwersytetu Marii Curie-Skłodowskiej, Lublin.

Dawidowicz D. (2008), Fundusze inwestycyjne. Rodzaje, typy, metody pomiaru i ocena efektywności, CeDeWu, Warszawa.

Jarosz D. (1997), DWS - kolejny fundusz powierniczy, „Parkiet”, 01.10.1997.

Miziołek T. (1998), Coraz więcej funduszy, „Nasz Rynek Kapitałowy”, 4, 70-72.

Miziołek T. (2001a), Rok funduszy dywidendowych, „Nasz Rynek Kapitałowy”, 124(4), 69-73.

Miziołek T. (2001b), Nowe fundusze na rynku, „Nasz Rynek Kapitałowy”, 129(9), 90-93.

Miziołek T. (2005), Rynek funduszy inwestycyjnych w Polsce rok po akcesji do Unii Europejskiej, [w:] Karpuś P., Węcławski J (red.), Przekształcenia rynku finansowego w Polsce, Wydawnictwo Uniwersytetu Marii Curie-Skłodowskiej, Lublin.

STFI (2001), Raport 2000, Warszawa. 
IZFiA (2005), Raport 2004, Warszawa.

IZFiA (2006), Raport 2005, Warszawa.

Królik K. (2005), Fundusze funduszy l' nowy produkt w ofercie TFI, [w:] Karpuś P., Węcławski J (red.), Przeksztatcenia rynku finansowego w Polsce, Wydawnictwo Uniwersytetu Marii Curie-Skłodowskiej, Lublin.

Multibank (2012), MultiBank - wprowadzi na rynek nowy produkt Centrum Oszczędzania, http://media.multibank.pl/pr/5313/multibank-wprowadzi-na-rynek-nowy-produktcentrum-oszczedzania (17.03.2012).

Parczewski J. (2001), Jak to z rynkiem było, „Parkiet”, 02.06.2001.

Perez, K. (2012), Fundusze inwestycyjne. Rodzaje, zasady funkcjonowania, efektywność, Wolters Kluwer Polska, Warszawa.

Potoczek P. (2011), Sekurytyzacja i fundusze sekurytyzacyjne, [w:] Perez K., Ziarko-Siwek U. (red.), Inwestycje finansowe, CeDeWu, Warszawa.

Przybylska-Kapuścińska W., Borowski G., (2004), Opodatkowanie inwestycji jako czynnik determinujacy rozwój polskiego rynku instytucji wspólnego inwestowania, [w:] Dziawgo D. (red.), Indywidualni inwestorzy na rynku finansowym, Wydawnictwo Uniwersytetu Mikołaja Kopernika, Toruń.

Siwek K. (2002), Oferta dla bogatych, „Parkiet”, 24.12.2002.

Siwek K. (2003a), TFI będa walczyć o gotówkę, „Parkiet”, 23.08.2003.

Siwek K. (2003b), Fundusze antypodatkowe gorsze od bonów?, „Parkiet”, 09.10.2003.

Ustawa z dnia 22 marca 1991 r. Prawo o publicznym obrocie papierami wartościowymi i funduszach powierniczych, Dz.U. 1991, nr 35, poz. 155.

Ustawa z dnia 29 grudnia 1993 r. o zmianie ustawy - Prawo o publicznym obrocie papierami wartościowymi i funduszach powierniczych, Dz.U. 1994, nr 4, poz. 17.

Ustawa z dnia 28 sierpnia 1997 r. o funduszach inwestycyjnych, Dz.U. 1997, nr 139, poz. 933 .

Ustawy z dnia 16 listopada 2000 r. o zmianie ustawy o funduszach inwestycyjnych, Dz.U. 2000, nr 114, poz. 1192.

Ustawa z dnia 27 maja 2004 r. o funduszach inwestycyjnych, Dz.U. 2004, nr 146, poz. 1576.

\section{CHANGES IN THE STRUCTURE OF THE MUTUAL FUNDS MARKET IN THE PERIOD OF 1991-2011 YEARS}

A b s t r a c t. Investment funds for several years, are important assets in the portfolios of individual and institutional investors. Due to increasingly stringent regulations are competitive in comparison to other asset classes. The purpose of this article is to present the changes in the structure of the investment fund market, with particular emphasis on the role of the determinants of legal and fiscal determinants.

K e y w or d s: mutual funds, polish mutual funds, unit trusts. 
